FIU Law Review

Volume 13

Number 1 Environmental Federalism

Article 9

Summer 2018

\title{
The Grid and the Grouse: Cooperative Federal-State Conservation Planning in the Ages of Obama and Trump
}

Bret Birdsong

bret.birdsong@unlv.edu

Follow this and additional works at: https://ecollections.law.fiu.edu/lawreview

Part of the Administrative Law Commons, and the Environmental Law Commons

Online ISSN: 2643-7759

\section{Recommended Citation}

Bret Birdsong, The Grid and the Grouse: Cooperative Federal-State Conservation Planning in the Ages of Obama and Trump, 13 FIU L. Rev. 103 (2018).

DOI: https://dx.doi.org/10.25148/lawrev.13.1.9

This Article is brought to you for free and open access by eCollections. It has been accepted for inclusion in FIU Law Review by an authorized editor of eCollections. For more information, please contact lisdavis@fiu.edu. 


\title{
The Grid AND THE Grouse: CoOperative Federal- State Conservation Planning in the Ages of OBAMA AND TRUMP
}

\author{
Bret Birdsong*
}

Introduction. 103

I. The Grid: Collaboration for Renewable Energy in the

California Desert. 104

A. The Imperatives of Renewable Energy in the California Desert. 105

B. The Shape of Extraordinary Collaboration in the DRECP......110

II. The Grouse: Sage Grouse Conservation Across Eleven

Western States

A. Saving the Sagebrush Sea: The Imperatives of Sage Grouse Conservation Cooperation

B. All Threats on All Lands: Knitting Together a Comprehensive Strategy Through Federal-State Cooperation

III. Conclusion: The Future of Collaborative Conservation

Management in the Trump Era.... 124

\section{INTRODUCTION}

It is as true as it is inconvenient, perhaps, that nature does not acknowledge, much less heed, the lines of legal jurisdiction. Gravity inexorably pushes water down, and water obeys, flowing where the earth poses the least resistance, except where engineers have intervened. And wildlife, though resistant to gravity, moves according to other of nature's motivating forces. Predators follow prey. If they can find it and get to it, animals will nest, or breed, or raise their broods, where the habitat provides the conditions fit for the purpose. Animals do not care whether the habitat is in one state or another, or whether it is on public or private land. Plants do not care, either.

But this is not to say that the lines on the map indicating jurisdictional boundaries or demarcating ownership do not matter to nature. Most importantly, those lines significantly influence-by determining the applicable legal regime - where human-induced disruptions to the natural world are located. Disruption of habitat as a result of human uses and development,

\footnotetext{
* Professor of Law, William S. Boyd School of Law, University of Nevada Las Vegas. From 2013 to 2016, he served as Deputy Solicitor for Land Resources at the U.S. Department of the Interior.
} 
whether residential, industrial, or infrastructural, is both enabled and limited by applicable law; and laws differ among jurisdictions. Moreover, the lines of legal authority and ownership often influence the quality of the habitat that remains by conditioning or limiting the uses and development that can occur in order to conserve habitat and other natural values. Where and how development occurs depends, in great part, on who owns the land and how law applies to the owner's choices.

This essay reviews two habitat conservation and planning initiatives undertaken by the Obama administration that relied on and envisioned extraordinary cooperation between the federal and state governments in order to overcome, or at least lessen, the disruptive impacts of jurisdictional lines on effective and comprehensive habitat conservation. These initiatives are the Desert Renewable Energy Conservation Plan (DRECP) in California and the sage grouse conservation planning effort across eleven western states. Both initiatives embraced the common sense goal of coordinating development and conservation management across jurisdictional boundaries. In both initiatives, however, cooperation was motivated and sustained by specific legal and policy imperatives that commanded a joint effort. In the Trump era to date, these imperatives, which are described below, remain mostly unchanged, notwithstanding shifts in federal policy favoring traditional energy development on the public lands. In a rational world unmanipulated by politics, these imperatives should operate to further promote - or, at the very least, to maintain intact - these collaborative conservation efforts.

\section{THE GRID: COLLABORATION FOR RENEWABLE ENERGY IN THE CALIFORNIA DESERT}

The Desert Renewable Energy Conservation Plan (known as the DRECP) was launched in 2008 as an unprecedented joint planning effort by federal agencies - most notably the Bureau of Land Management (BLM) and the Fish and Wildlife Service (FWS) - and California state regulatory agencies responsible for permitting energy development. ${ }^{1}$ Its purpose was to engage in coordinated planning for both renewable energy development and habitat conservation measures in the desert region of Southern California. ${ }^{2}$ The planning area covers some 22.5 million acres, ranging from the Owens Valley in the North to the Mexican border in the South, and from the

1 Bureau of LAND MgMt., U.S. DeP'T of THE INTERIOR, BLM/CA/PL-2016/03+1793+8321,

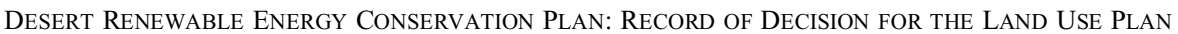
AMENDMENT TO THE CALIFORNIA DESERT CONSERVATION PLAN, BiSHOP RESOURCE MANAGEMENT Plan, And Bakersfield Resource Management Plan 2 (2016) [hereinafter DRECP ROD], https://www.drecp.org/finaldrecp/rod/DRECP_BLM_LUPA_ROD.pdf.

2 Id. 
Tehachapi and San Gabriel Mountains in the West to the Colorado River and the border with Nevada in the East ${ }^{3}{ }^{3}$ an area about the size of the Florida peninsula. The first phase of the effort was completed in 2016 with the adoption of federal land management planning amendments by the BLM that established development focus areas (DFAs) for utility scale renewable energy projects and adopted habitat conservation measures to ensure that the development in the DFAs would not compromise the biological integrity of desert habitat for species of concern to both the federal government and California. ${ }^{4}$ Under current plans, the federal plans will be followed by consonant, statedeveloped conservation plans that will provide "take" coverage under California law and allow renewable developers to proceed. ${ }^{5}$

\section{A. The Imperatives of Renewable Energy in the California Desert}

The imperatives for federal-state cooperation in the DRECP weighed on both the development and the conservation sides of the ledger. Renewable energy development, including utility-scale solar and wind electric generation and transmission, largely arose in the United States after the turn of the twenty-first century as a response to growing awareness of global climate change. California led the charge of states adopting aggressive policies to promote renewable energy, pledging in 2006 to reduce its greenhouse gas emissions to 1990 levels by 2020 and eighty percent below those levels by $2050{ }^{6}$ A centerpiece of its climate program is the renewable portfolio standard (RPS) - a legal requirement for retail electricity sellers to include a certain proportion of renewable energy as part of their overall portfolio. ${ }^{7}$ In 2002, California adopted its first RPS, requiring electric utilities to achieve a mix of twenty percent renewable energy by 2017 —not the first, but the most striving RPS at the time. ${ }^{8}$ In 2011, California revised upward its RPS goal to thirty-three percent by 2020 and set interim goals of twenty percent by 2013 and twenty-five percent by $2016 .^{9}$ In October 2015, as the DRECP entered

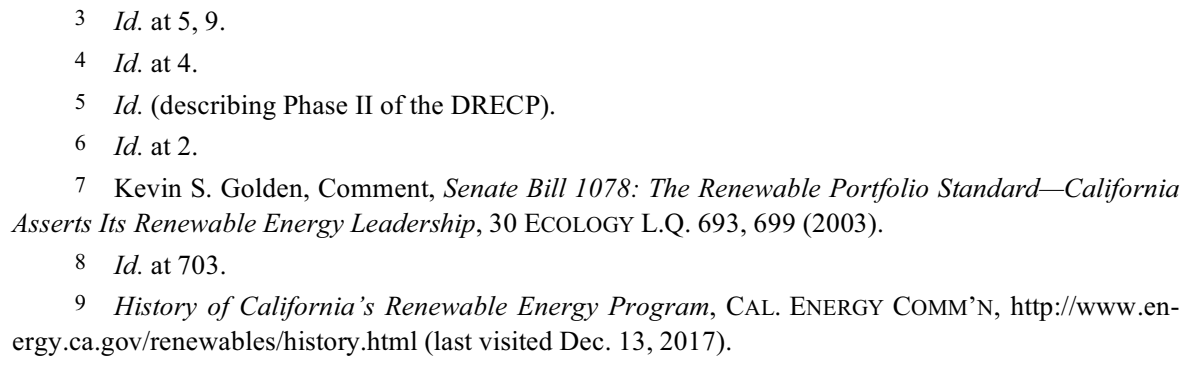

9 History of California's Renewable Energy Program, CAL. ENERgy COMM'N, http://www.energy.ca.gov/renewables/history.html (last visited Dec. 13, 2017). 
its final stages of development, California again increased its RPS, this time to fifty percent by $2030 .^{10}$

California's RPS policies spiked demand for the generation of renewable energy on a utility scale, using sunny and windy desert lands as a base. At the onset of California's RPS program, installed generation capacity in the state was less than $400 \mathrm{MW}$ (megawatts) for solar and only about 1,500 MW for wind. ${ }^{11}$ Those numbers have swelled to 9,867 for solar and 5,644 for wind in 2016. ${ }^{12}$ Though some of that capacity was from distributed generation, more than $10,000 \mathrm{MW}$ of large-scale renewable energy generating capacity has come online since $2011 .^{13}$

California found a willing partner in the federal government in its desire to promote renewable energy development. The federal effort to promote renewable energy development began in earnest in the 2005 Energy Policy Act, which set a goal of approving 10,000 MW of renewable energy generation on federal public lands by 2015 and provided tax incentives and loan guarantees for renewable energy technology. ${ }^{14}$ Secretary of the Interior Ken Salazar issued several Secretarial Orders to prioritize renewable energy development on public lands, and President Obama doubled down on renewable energy, upping the public lands renewable energy goal to 20,000 MW by 2020 in his Climate Action Plan. ${ }^{15}$

There are imperatives for federal-state cooperation on the conservation side, too, which were heightened by the close proximity of the solar and wind resources of California's fragile desert to the largest energy markets in the state. Mushrooming demand for renewable energy development in California, as much as it benefits the environment by building carbon-free sources of electricity, poses particular regional and localized environmental concerns. ${ }^{16}$ These concerns start with the direct impacts of utility scale energy development. A typical solar generating project converts several thousand acres of desert land, which often is functioning wildlife habitat, into single-

10 Felix Mormann et al., A Tale of Three Markets: Comparing the Renewable Energy Experiences of California, Texas, and Germany, 35 Stan. Envtl. L.J. 55, 78-79 (2016). California supplemented the RPS with other policies to promote renewable energy production, including promotion of distributed generation, such as rooftop solar. $I d$. at 79-80. But these policies did not impact the demand for desert land for utility scale renewable generation in the same manner as the RPS.

11 Tracking Progress, California's Installed Electric Power Capacity and Generation, CAL. ENERGY COMM'N 4, http://www.energy.ca.gov/renewables/tracking_progress/documents/installed_capacity.pdf (last updated Aug. 2017).

12 Id.

13 Tracking Progress, Renewable Energy - Overview, CAL. ENERGY COMM'N 3, http://www.energy.ca.gov/renewables/tracking_progress/documents/renewable.pdf (last updated Dec. 2017).

14 DRECP ROD, supra note 1 , at 2.

15 Id.

16 See, e,g., Amy Wilson Morris \& Jessica Owley, Mitigating the Impacts of the Renewable Energy Gold Rush, 15 MinN. J.L. SCI. \& TECH. 293, 297-98 (2014). 
purpose, industrialized land covered entirely by structures. ${ }^{17}$ Wind turbines, though they permit compatible ground-level uses by wildlife and people, pose unique threats to bats and birds. ${ }^{18}$ Transmission lines to move the electricity from the generating plant to market, cut linear paths through desert and ranges, fragmenting habitat and often providing assistance to avian predators, like hawks and ravens. ${ }^{19}$

At the onset of the renewables revolution, federal law provided no unified framework for deciding whether and where to locate renewable energy production on public land. The BLM, which administers most federal land with the greatest solar and wind potential, is authorized under its organic statute, the Federal Land Policy and Management Act (FLPMA), to grant rightsof-way to private entities to construct and operate energy projects; but that authority had not typically been applied to renewable energy projects, which by their nature occupy vast areas of land.$^{20} \mathrm{Few}$ restrictions exist on the BLM's right-of-way authority, but any grant must be "in the public interest," ${ }^{21}$ conform to the applicable land use management plan, ${ }^{22}$ and avoid "unnecessary or undue degradation of the land. ${ }^{, 23}$ Because interest in using public lands for solar development ballooned relatively suddenly, few, if any, BLM land use plans provided meaningful guidance or limitations about where utility scale renewable energy development was suitable. In the absence of such guidance, BLM land managers would field discrete applications for rights-of-way and process them under the other criteria, with information from environmental reviews under the National Environmental Policy Act (NEPA) and the Endangered Species Act (ESA), where applicable, to help them determine whether the environmental impacts would be acceptable. ${ }^{24}$

17 E.g., id. at 363 (describing the Genesis solar project near Riverside, California).

18 See generally U.S. Fish \& WiLdLIFE SERV., U.S. DeP'T OF THE INTERIOR, OMB CONTROL No. 1018-0148, LAND-BASED WIND ENERGY GUIDELINES (2012), www.fws.gov/ecological-services/es-library/pdfs/WEG_final.pdf.

19 E.g., Bureau OF LAND MGMT., U.S. DEP'T OF THE INTERIOR, DOI-BLM-ID-0000-0002-EA, GateWAy West 500-KV TRANSMission Line ProjeCt SEgments 8 and 9, Final ENVIRONMENTAL Assessment and PROPOSED LAND Use Plan Amendments, IDAHO H17-18 (2018), https://eplanning.blm.gov/epl-front-office/pro-

jects/nepa/92974/130144/158276/2_GWW_EA_FINAL_JAN2018_wo_appendices.pdf.

2043 U.S.C.A. § 1761(a) (West 2017) (known as Title V).

21 Id.

2243 U.S.C.A. § 1732(a) (West 2017) ("The Secretary shall manage the public lands under principles of multiple use and sustained yield, in accordance with the land use plans developed by him ....").

$23 I d$. at $\S 1732$ (b) ("In managing the public lands the Secretary shall, by regulation or otherwise, take any action necessary to prevent unnecessary or undue degradation of the lands.").

24 National Environmental Policy Act of 1969, 42 U.S.C. $\S \S 4321-4370$ (2012); Endangered Species Act, 16 U.S.C. $\S \S 1531-1544$ (2012). 
One response to the onslaught of BLM solar energy right-of-way applications in California and other southwestern states was the BLM's recognition that the consideration of the overall environmental impacts of solar development would better be done through programmatic, rather than discrete, project-level analysis. ${ }^{25}$ In 2008 , the BLM launched a six-state planning process to consider where to affirmatively plan for solar energy development, where to avoid it, and where to consider it on the individual merits of the project. ${ }^{26}$ The Western Solar Plan, which included a programmatic environmental impact statement and amendments to BLM plans, ${ }^{27}$ was a form of deconfliction planning. Through the process, the BLM identified Solar Energy Zones (SEZs) where the studies showed that utility scale solar energy development would be smart from both a resource-development perspective, taking into account factors like the quality of the solar resource and transmission needs, and also from a conservation perspective, taking into account the quality of the wildlife habitat and other environmental values of particular places. ${ }^{28}$ As a matter of policy, the BLM would favor development in the SEZs and forbid it in the places where it chose to prioritize other values, such as habitat. ${ }^{29}$

The Western Solar Program served as a template for large-scale planning to resolve conflicts between renewable energy development and conservation, but it did not resolve the full problem, especially in the California desert. One reason was the patchwork of federal-state jurisdiction and land ownership. Federal ownership predominates in the California desert, but deconfliction planning solely on federal land provided an incomplete solution. As a general matter, federal land, with its large, substantially intact areas of habitat, offered better opportunities for conservation gains (both through protection of those lands from habitat-harming activities, and through affirmative restoration and protection actions).$^{30}$ At the same time, privately owned land was generally more attractive to project proponents for solar and wind development than federal land because of its closer proximity to

251 Bureau of LAND MGMt., U.S. DeP'T OF THE INTERIOR \& U.S. DEP'T OF ENERGy, FES1224; DOE/EIS-0403, FinAl Programmatic ENVIRONMENTAl IMPACT STATEMENT (PEIS) FOR SOlAR ENERGy DEVElopment IN SIX SOUTHWESTERN StATES ES-2-ES-3 (2012), https://www.energy.gov/sites/prod/files/EIS-0403-FEIS-Volume1-2012_0.pdf (describing the purpose and need for the Western Solar Program).

26 Id.

27 Bureau of LAND MGMt., U.S. DEP'T OF THE INTERIOR, APPROVED RESOURCE MANAGEMENT PLAN AMENDMENTS/RECORD OF DECISION (ROD) FOR SOLAR ENERGY DEVElOPMENT IN SIX SOUTHWESTERN STATES 1 (2012), http://solareis.anl.gov/documents/docs/Solar_PEIS_ROD.pdf.

28 Id. at $5-6$.

29 Id. at 4-5.

30 See generally DRECP ROD, supra note 1, at 14-25 (describing the conservation values of the federal lands within the DRECP planning area). 
infrastructure and the fact that much of it was already disturbed. ${ }^{31}$ Land use planning regulation and permitting of energy projects on private land development, of course, is a matter for counties and state officials, not the federal government.

The significant role of state permitting jurisdiction, coupled with the disproportionate opportunity for conservation gains on federal land, presented a key reason for the federal-state collaboration in the DRECP. California law imposes a number of strict requirements for mitigation of development on private or state land that impacts habitat of protected species. These requirements are, in some instances, stricter than federal law. Most importantly, the Natural Communities Conservation Plan Act (NCCPA), ${ }^{32}$ requires an approved, regional natural communities conservation plan (NCCP) in order for state agencies to permit any activity that will result in a "take" of a protected species. The California Department of Fish and Wildlife (CDFW), which administers the law, requires an NCCP to provide for the conservation of species "in perpetuity," and, moreover, to include conservation actions that achieve a conservation gain for the affected species. ${ }^{33}$ The NCCP must do more than merely offset adverse impacts to protected species and habitat.

The stringent requirements of California law sharpened the imperative for federal-state cooperation. Given the relative scarcity of conservation opportunities on private and state land in the California desert, much of the conservation gain necessary to satisfy the NCCP requirements would likely have to come from conservation actions on federal land. So, in sum, the bargain of imperatives boiled down to three things. First, both federal and state policies strongly promoted utility-scale renewable energy development. Second, the patchwork of ownership and jurisdiction over lands in the California desert

31 See Bureau of LAND MGMT., U.S. DEP'T OF THE INTERIOR, DRECP PROPOSED LUPA AND FINAL EIS app. F at F-5 (2015), https:/www.drecp.org/finaldrecp/pdf_files/Executive_Summary_Ltr-toReader_Table-of-Contents_Glossary/02_Executive_Summary.pdf.

32 Natural Community Conservation Planning Act of 1991, CAL. FISH \& GAME CODE, $\S \S 2800-$ 2835 (West 2018).

33 See id. at $\S 2820$ (requiring that the implementation plan for an NCCP "to ensure that implementation of mitigation and conservation measures on a plan basis is roughly proportional in time and extent to the impact on habitat or covered species authorized under the plan"). Policy guidance from the California Department of Fish and Wildlife under the analogous California Endangered Species Act for mitigation on public lands states:

The fish and wildlife resources or environments replaced or substituted for those impacted must be maintained in perpetuity. There may be cases where some impacts of the take are temporary such that the credit (offsetting value) would not need to be in perpetuity. If the fully mitigated standard can be met on conserved or publicly owned lands and the mitigation and land are protected in perpetuity, the mitigation may proceed if it is consistent with the policy.

CAl. DeP'T of Fish and Game, Policy for Mitigation on Publicly Owned, DePartment Owned AND CONSERVED LANDS (2012), https://www.water.ca.gov/LegacyFiles/floodsafe/fessro/docs/flood13_dfg.pdf. 
meant that neither the state nor the federal government could fully balance conservation and development objectives on their own. Third, and most specifically, the stringent requirements of the NCCPA meant that only a coordinated federal-state planning effort could achieve the level of conservation necessary to greenlight sufficient renewable energy development because the best conservation opportunities lie on federal land.

\section{B. The Shape of Extraordinary Collaboration in the DRECP}

The DRECP was conceived as an interagency planning process, involving relevant federal and state agencies, to jointly plan for uses of federal and nonfederal land in the 22.5 million-acre planning area to meet both renewable energy development and conservation goals and satisfy legal requirements under both federal and state law. The bureaucratic formulation of that description masks the deep complexity of the effort and the extraordinary cooperation necessary to pull off such an unprecedented decision making process. In the end, as described below, it did not quite go as planned, with the BLM and California agencies deciding to phase their decisions. ${ }^{34}$ Even so, and despite that the California agencies have yet to complete their process, the cooperative effort stands as an important example of how cross-jurisdictional planning can serve to overcome the challenges of disjointed ownership and regulatory authority.

That the BLM and the California agencies decided to participate in coordinated, cross-jurisdictional land use planning itself was a notable measure of cooperation. In 2010, two federal agencies (BLM and FWS) and two California agencies (CDFW and the California Energy Commission (CEC)) entered into a Planning Agreement ${ }^{35}$ that outlined goals and roles of the agencies. The parties agreed to the twin goals of streamlining the permitting of renewable energy development and providing for the long-term conservation of biological resources, including native species and their habitat, within the planning area. ${ }^{36}$ They further agreed that the goals included: (1) to "[p]rovide a framework for a more efficient process by which proposed renewable energy projects within the Planning Area may obtain regulatory authorizations and which results in greater conservation values than a project-by-project, species-by-species review would have;" (2) to cooperate in the collection of the "best available scientific information" and base their planning decisions on that information; (3) to provide a means for renewable energy projects to

34 DRECP ROD, supra note 1 , at 4.

35 Cal. Dep't of Fish \& Game et al., Planning Agreement for the Desert Renewable ENERGY CONSERVATION PLAN (2010), https://nrm.dfg.ca.gov/FileHandler.ashx?Documen$\mathrm{tID}=29285 \&$ inline.

36 Id. at 6. 
comply with the relevant federal and state regulatory schemes and obtain regulatory assurances in the form of incidental take permits under the federal ESA and California NCCPA, and (4) to "[p]rovide a comprehensive means to coordinate and standardize mitigation and compensation requirements." In essence, the agencies agreed to use their relevant authorities and planning processes in concert with each other to promote the twin goals of the DRECP, including the stringent requirements of the NCCPA. Even as they agreed to do so, however, the ambition, as well as the uncertainty, of the endeavor was clear to them. The parties specifically recognized that "until conservation strategies are developed for the Covered Species and their habitats ... the cost and feasibility of achieving these goals will not be known." 38

At the outset, the DRECP envisioned each of the four agencies to be undertaking a specific planning process in coordination with each of the others. On the federal side, the BLM would undertake to amend its applicable land use plans to promote the DRECP goals, and the FWS, as the agency responsible for administering the federal ESA, would prepare a general conservation plan. ${ }^{39}$ On the state side, the $\mathrm{CDFW}$, the California wildlife regulatory agency, would prepare an NCCP to ensure the conservation of biological resources and provide a basis for issuing take permits to energy developers. ${ }^{40}$ The CEC, with its overall responsibility for meeting California's RPS and specific state permitting authority over thermal power plants, would be an applicant to the FWS for a take permit under section 10 of the Federal ESA. ${ }^{41}$

The Herculean task of coordinating the four agencies and meeting the goals of the DRECP led, eventually, to a draft DRECP and environmental impact statement (EIS) that encompassed more than 12,000 pages of analysis. $^{42}$ The Draft DRECP evaluated five alternatives, all of which were projected to provide for the development of about 20,000 MW of renewable

37 Id. at 7.

38 Id.

39 As a matter of FWS policy, a general habitat plan is a way to streamline ESA compliance for small, disparate actors, especially private individuals or entities, similar to a general permit. By creating a general plan focusing on measures that conserve target species, the general conservation plan provides a means for applicants to obtain incidental take permits under Section 10 by demonstrating that their project conforms to the measures outlined in the GCP. See U.S. FISH \& WILDLIFE SERV., U.S. DEP'T OF INTERIOR, FWS/AES/DCHRS/032359, FINAL GENERAL CONSERVATION PLAN POLICY (2007).

$40 \quad$ Id. at 8.

41 CAl. Energy Comm'N, Draft Desert Renewable EnERgy CONSERVATION Plan I.0-8 (2014) [hereinafter Draft DRECP \& EIS], https://www.drecp.org/draftdrecp/ (download from "Volume I: Background and Planning Process" hyperlink).

42 Just the Table of Contents for the Draft DRECP and EIS ran to 105 pages. Id. at TOC-1-TOC106. 
energy capacity by 2040 , while providing for conservation of biological resources. $^{43}$

Perhaps the most remarkable and innovative example of the extraordinary coordination in the DRECP centers on the issue of mitigation, specifically the effort to make federal land resources available for durable mitigation measures that would satisfy the strict requirements under California law, particularly the NCCPA. The idea is rather simple: use federal land use authorities to provide conservation on public lands so that energy developers may gain credit for the conservation as mitigation of the impacts of their projects (and comply with the NCCP). But this simple idea turns out to be something of a Gordian knot.

The reason is a tension between the paradigms underlying federal land use planning and conservation planning under state law. FLPMA mandates that the BLM manage the public lands for multiple use and sustained yield through a process of land use planning and individual management decisions that conform to the land use plans. ${ }^{44}$ Flexibility is an essential underlying principle, and FLPMA generally provides that any land use designation made solely through planning - for instance, the decision to exclude certain land uses, such as renewable energy development or habitat conservation - can be revisited and changed or revoked by amending or revising the land use plan. ${ }^{45}$

But flexibility, insofar as it erodes confidence that the conservation benefits of a land use decision will be enduring, is anathema to conservation planning for biological resources on the brink, such as many of those with which the DRECP is concerned. Basic conservation accounting principles hold that, when habitat is disturbed by development, any mitigation measures must be additional to what would otherwise have occurred and also provide conservation benefits that will endure as long as the impacts to be mitigated. ${ }^{46}$

An example demonstrates this dynamic. Suppose that a solar generating farm will directly destroy 1,000 acres of threatened desert tortoise habitat and degrade another several thousand acres because of transmission lines, roads, and other disturbances. A typical economic lifespan of such an installation might be forty years. On private land, the permission to use land could be

43 CAl. EnERgy COMM'N, Draft Desert Renewable Energy CONSERVATion Plan EXECUTIVE SUMMARY 16 (2014), http://www.drecp.org/draftdrecp/files/a_Front_Matter_and_Executive_Summary/Draft_DRECP_Executive_Summary.pdf.

4443 U.S.C. $\$ 1732$ (a) (2012).

4543 U.S.C $\S 1712(a), 1712$ (e) (2012) (“"[M]anagement decisions to implement land use plans ... (1) ... shall remain subject to reconsideration, modification, and termination through revision ... of the land use plan involved.”)

46 The Energy \& Climate Change Task Force, U.S. DeP’T of the Interior, A Strategy FOR IMPROVING THE MitigATION POLICIES AND PRACTICES OF THE DEPARTMENT OF THE INTERIOR: A REPORT TO THE SECRETARY OF THE INTERIOR 6 (2014), https://www.doi.gov/sites/doi.gov/files/migrated/news/upload/Mitigation-Report-to-the-Secretary_FINAL_04_08_14.pdf. 
secured by a forty-year lease. Certainly, any effective mitigation of the impacts of the project would have to be designed with the reasonable expectation that the conservation benefits would last forty years. But there is also the possibility, perhaps even a probability that the project lease would be renewed and refurbished, leading to lengthier impacts. Even if the project is ended and dismantled at the end of its economic life of forty years, the degraded land would not immediately serve as functioning habitat. In desert environments, where the rehabilitative forces of nature are extremely slow, the degradation of habitat values might effectively be permanent, particularly if one applies discounting principles for habitat that is restored only decades in the future. In such an example, effective mitigation of the impacts would require the commitment of equivalent habitat and land resources to permanent protection.

Under California's NCCPA, permanence has become the gold standard of mitigation for development impacts. ${ }^{47}$ When conservation opportunities exist on private land, permanence is readily achievable through the use of conservation easements. Conservation easements create property interests in the holder to prevent the landowner from engaging in certain activities that would affect the conservation value of the land or to require the land owner to maintain certain conservation conditions on the land. When conservation opportunities exist on public land, subject to management under FLPMA, achieving long-lasting or permanent conservation benefits to mitigate development presents a challenge. Conservation easements held by nonfederal entities, such as state wildlife agencies, are not workable because they require a transfer of a federal property interest. ${ }^{48}$ So conservation benefits may be secured through the mechanisms provided by FLPMA, namely, planning designations, which are inherently changeable, and other management actions, which must conform to applicable land use plans.

The DRECP agencies sought to loosen this Gordian knot through a formal agreement to address mitigation, particularly the need to use federal land to durably mitigate the impacts of development on private land. ${ }^{49}$ The Durability Agreement sets forth a process for the consideration of cross-jurisdictional mitigation and identifies specific tools that may be applied on BLM lands to achieve mitigation for impacts on private lands subject to CDFW jurisdiction. These tools range from authorizing physical actions to protect or enhance habitat, like fencing along roads and highways and restoration of habitat, to management changes designed to enhance conservation outcomes,

47 Bureau of Land Mgmt., U.S. DeP'T of the Interior \& Cal. DeP'T of Fish \& WildLife, Agreement to CONSERVE Biological and NATURAL RESOURCES ON FEDERAL Public LANDS ADMINISTERED BY THE BLM WiTHIN CALIFORNIA 2 (2015) [hereinafter DuRABILITY AGREEMENT].

4843 U.S.C.A. 1713 (West 2017) (describing the criteria limiting the sale of federal public land).

49 DURABILITY AGREEMENT, supra note 47, at 1. 
such as increasing law enforcement and educational outreach or retiring lands from livestock grazing. ${ }^{50}$ The agreement also specifies a number of specific legal authorities available to the BLM to allow these conservation tools to be applied by third parties on public lands, such as rights-of-way and other use authorizations. ${ }^{51}$

Two innovations of the Durability Agreement stand out. First, it specifies a detailed process for the state regulatory agency, CDFW, to request the BLM to exercise its authority specifically for the purpose of providing conservation benefits that would mitigate the impacts of development. Under the agreement, the CDFW, in the course of considering whether to approve an application for renewable energy development on private land, may look for mitigation opportunities on certain BLM lands identified by the DRECP and work cooperatively with the BLM in an effort to obtain BLM authorization that would secure the envisioned mitigation benefits. In other words, the BLM agreed to consider making management decisions relating to the use of public lands, on a case-by-case basis, for the specific purpose of generating conservation benefits that could be credited by CDFW toward mitigation requirements for renewable energy projects.

Second, the Durability Agreement seeks to meaningfully enhance the durability of BLM management decisions when the CDFW has actually credited those decisions toward satisfaction of mitigation requirements under California law. The agreement acknowledges that, even if FLPMA or other federal law reserves to the BLM flexibility to change land use designations, the BLM will attempt to secure conservation benefits of its management decisions for as long as the CDFW recognizes the mitigation value of those decisions. ${ }^{52}$ Further, the agreement embodies the principle that any conservation actions intended to mitigate the impacts of development should last as long as the impacts themselves. Finally, the agreement provides for consultation between the CDFW and the BLM before the BLM either changes the conservation designation or considers any application by a third party for a project on land that has been recognized by the CDFW as providing mitigation. ${ }^{53}$ The purpose of the consultation is to work cooperatively to ensure that the land use changes or third-party project, if approved, would not impair the mitigation values recognized by CDFW.

The future of the DRECP is increasingly unclear. In early 2018, the BLM initiated a review of the 2016 DRECP amendments in light of President Trump's direction to review actions that might burden domestic energy

\footnotetext{
$50 \quad I d$. at 3.

51 Id. at 3-4.

52 Id. at 6.

53 Id. at 7.
} 
production and to reduce impediments to broadband infrastructure development. ${ }^{54}$ But the imperatives remain for federal-state cooperation in planning for both resource development and the conservation of habitat that make that development possible.

\section{The Grouse: SAge Grouse Conservation ACross ELEVEN WESTERN STATES}

In September 2015, flanked by the governors of Wyoming, Colorado, and Nevada, Secretary of the Interior Sally Jewell announced the momentous determination by the FWS that the iconic greater sage grouse was not warranted for listing under the federal ESA. ${ }^{55}$ The decision came after years of petitions and litigation over the status of the grouse, including the FWS's determination five years earlier that the bird was warranted for listing but precluded by the agency's need to attend to more imperiled species with its scarce resources. ${ }^{56}$

The joint federal and state effort to adopt conservation measures for the greater sage grouse was a landmark conservation achievement of the Obama administration and western governors, and it operates at a scale that dwarfs the DRECP. Like the DRECP, the collaborative sage grouse conservation effort came about because compelling imperatives imposed by law and by the fact of disjointed ownership and jurisdiction of the lands where the grouse makes its home. Like the DRECP, the sage grouse conservation effort involved extraordinary cooperation between federal land management and wildlife agencies and their counterparts in state government. But the story follows a different arc than the DRECP, with cooperation a more stumbling, though still essential, element to the success of the effort.

\section{A. Saving the Sagebrush Sea: The Imperatives of Sage Grouse Conservation Cooperation}

An understanding of the imperatives for federal-state cooperation in sage grouse conservation begins with the sweeping historic range of the bird

54 Notice of Intent to Amend the California Desert Conservation Area, Bakersfield, and Bishop Resource Management Plans and Prepare Associated Environmental Impact Statements or Environmental Assessments, 83 Fed. Reg. 4921-22 (Feb. 2, 2018).

55 See Clifford Krauss, U.S. Trying to Protect Sage Grouse without Listing it as an Endangered Species, N.Y. TIMES, Sept. 22, 2015, at B6.

56 Endangered and Threatened Wildlife Plants; 12-Month Finding on a Petition to List Greater Sage-Grouse (Centrocercus urophasianus) as an Endangered or Threatened Species, 80 Fed. Reg. 59,858942 [hereinafter FWS 2015 Not Warranted Finding] (proposed Oct. 2, 2015) (to be codified at 50 C.F.R. pt. 17). 
and its diminished, though still broad, range today. Before European settlement, sage grouse occupied habitats that today stretch across thirteen states and three Canadian provinces, covering 460,000 square miles. ${ }^{57}$ Its population is thought once to have been as high as 16 million, though estimation is difficult. ${ }^{58}$ Today, the bird occupies just fifty-six percent of that historic range, though it is still found in eleven western states, ranging from California to North Dakota, and two Canadian provinces. ${ }^{59}$ Its population has been in long-term decline since at least the $1960 \mathrm{~s} .{ }^{60}$ Sage grouse are a sagebrush obligate species, occupying the vast sagebrush valleys that predominate the western landscape, and tend to group in core areas within the range. More than two-thirds of the greater sage grouse population exists in two areas centered on Wyoming and northern Nevada/central Idaho. ${ }^{61}$ As a general matter, sage grouse like to be left alone. They do not like their sagebrush-dominated habitat to be disturbed much by human activities or by fire. ${ }^{62}$ The expansive nature of sage grouse habitat, combined with the diminishment of that habitat and grouse populations by human activity, frames the imperatives for federalstate cooperation in sage grouse conservation. Those imperatives were both legal and physical.

The legal imperative for the sage grouse collaboration took the form of the federal ESA. Beginning in 1999, environmental advocates filed eight separate petitions with the FWS to list the sage grouse or distinct population segments of the bird to harness the protections of the Act. ${ }^{63}$ The FWS first responded to these petitions in 2005, finding the grouse not warranted for listing, but that determination did not withstand judicial scrutiny. ${ }^{64}$ A 2010 reconsideration of the species's status resulted in a finding that the grouse was warranted for listing but precluded by higher priority conservation demands on FWS. ${ }^{65}$ That finding, too, led to litigation. Environmental

57 Id. at 59,864 .

58 Endangered and Threatened Wildlife and Plants; 90-day Finding for Petitions To List the Greater Sagegrouse as Threatened or Endangered, 69 Fed. Reg. 21,484-94 (proposed Apr. 21, 2004) (to be codified at 50 C.F.R. pt. 17).

59 FWS 2015 Not Warranted Finding, supra note 56, at 59,864.

60 See id. at 59,868-70.

61 Id. at 59,865 (describing management zones II and IV defined by the Western Association of Fish and Wildlife Agencies).

62 U.S. Fish \& Wildlife SERV., U.S. DeP'T OF THE INTERIOR, GREATER SaGe-Grouse (CENTROCERCUS UROPHASIANUS) CONSERVATION OBJECTIVES: FINAL REPORT 8-11 (2013) [hereinafter CONSERVATION OBJECTIVES], https://www.fws.gov/greatersagegrouse/documents/COT-Report-withDear-Interested-Reader-Letter.pdf

63 FWS 2015 Not Warranted Finding, supra note 56, at 59,859.

64 See W. Watersheds Project v. Fish \& Wildlife Serv., 535 F. Supp. 2d 1173 (D. Idaho 2007).

65 Endangered and Threatened Wildlife and Plants: 12-Month Findings for Petitions to List the Greater Sage-Grouse (Centrocercus urophasianus) as Threatened or Endangered, 75 Fed. Reg. 13,90914,014 (proposed Mar. 23, 2010) (to be codified 50 C.F.R. pt. 17). 
advocates alleged that the FWS arbitrarily determined that it was "precluded" from writing a listing rule for the sage grouse and asked the court to require the FWS to list the species to trigger the protections of the ESA ${ }^{66}$ Although the case was not litigated to finality, the FWS agreed, in connection with another broad-based challenge to the FWS's long listing backlog, to reconsider the status of the sage grouse by September 30, 2015. ${ }^{67}$

The 2010 finding that the greater sage grouse was warranted for listing, coupled with the timeline to reconsider the status of the species in 2015, set the table for the cooperation that was to follow. The prevalence of federal land throughout the range of the sage grouse means that much of the economic activity in sage grouse country depends in some way on the uses of federal land, including mining for sand and gravel or other minerals, oil and gas development, renewable energy, recreation, and livestock grazing. A listing of the bird would trigger the twin protections of the ESA - sections 7 and 9-and would reach the regulatory hand of the ESA into nearly all activities on federal land and many on private land where sage grouse habitat exists. Under section 7, not only actions directly undertaken by federal land managers, but any that required their approval, would be subject to review by the FWS to ensure they did not jeopardize the continued existence of the sage grouse and the FWS's suggestion of reasonable alternatives or measures to protect the bird. ${ }^{68}$ In addition, fully nonfederal activities would be constrained not to "take" sage grouse by killing or harming them, or even destroying their habitat, unless the activities were protected by permits issued in accordance with habitat conservation plans ${ }^{69}$ Given the determination that the bird was warranted for listing and the alleged infirmity of the "precluded" finding, these default rules presaged the potential for stringent federal regulation of a wide array of economic activity in the eleven states where sage grouse occupy.

Inasmuch as the "warranted" finding suggested the real possibility of stringent federal regulation, it also suggested a narrow pathway toward avoiding the possibility. Among the factors the FWS considers in assessing the status of a species for a listing determination is the adequacy of regulatory mechanisms in place (besides the ESA) to conserve species and their habitats. ${ }^{70}$ A strong regulatory effort by states and federal agencies that control

66 Complaint at 1, 25, W. Watersheds Project v. U.S. Fish \& Wildlife Serv., 535 F. Supp. 2d 1173 (D. Idaho 2007) (No. 06-CV-00277).

67 U.S. DeP'T of Interior, Historic Conservation Campaign Protects Greater SageGROUSE (2015), https://www.doi.gov/pressreleases/historic-conservation-campaign-protects-greatersage-grouse (last updated May 10, 2017).

68 Endangered Species Act of $1973 \S 7(3)(a), 16$ U.S.C.A. $\S 1536(3)$ (a) (West 2017).

69 Id. § 9(b)-(c), 16 U.S.C.A. § 1538(b)-(c); id. § 10(a)(1)(A), (j), 16 U.S.C.A. § 1539(a)(1)(A), (j).

70 Id. § 4(a), 16 U.S.C.A. § 1533(a). 
activities that affect the habitat of a candidate species can lead to a justified conclusion that the measures will reduce peril to the species enough that it will not be in danger of extinction within a foreseeable time, even if the species would hurtle toward that precipice without the regulatory protections. ${ }^{71}$ The fact that the FWS believed in 2010 that there was room for improvement of the non-ESA regulatory mechanisms to protect the sage grouse meant that listing, and the feared economic disruption that might accompany it, could be avoided by adopting effective regulations that would be less costly than the full suite of ESA protections.

These legal imperatives for cooperation were certainly necessary ingredients to the collaboration, but they might not have been sufficient in themselves to make it happen. The remaining ingredient was supplied by the physical pattern of land ownership and the way the lines of jurisdiction fall on the habitat of the grouse. Although federal ownership predominates, the United States owns only about sixty percent of occupied sage grouse habitat, and the two multiple-use agencies with the most regulatory levers, the BLM and the Forest Service, manage only about fifty-one percent of the habitat. ${ }^{72}$ Nearly as much occupied habitat is owned privately (thirty-nine percent) or by state governments (five percent).$^{73}$ Furthermore, sage grouse use different kinds of habitat for different purposes and life stages, and that habitat is not evenly distributed. Mesic habitat - wet areas offering access to water year round, such as springs and wet meadows - provide essential habitat for sage grouse during the summer months when they are still rearing their young. ${ }^{74}$ As a result of historical patterns of land settlement in the American west, which often transferred government title to settlers who could establish homesteads (something only possible near water sources), much of this mesic habitat disproportionately sits on private land. ${ }^{75}$

The clear implication of the land ownership map of sage grouse habitat was that better regulating activities on federal land alone to conserve sage grouse would likely not be enough to keep the bird off the endangered or threatened species list. Even though significant economic activity in the intermountain west involves federal lands, local and state governments might have been content to leave it to the feds to do the regulating necessary for sage grouse conservation. But, with such a high proportion of habitat located

71 See FWS 2015 Not Warranted Finding, supra note 56, at 59,873; Policy for Evaluation of Conservation Efforts, 68 Fed. Reg. 15,100 (March 28, 2003) (to be codified at 50 C.F.R. ch. IV) (providing a framework and guidance for the consideration of conservation efforts in listing decisions under the ESA).

72 See FWS 2015 Not Warranted Finding, supra note 56, at 59,866.

73 Id.

74 J.P Donnelly et al., Public Lands and Private Waters: Scarce Mesic Resources Structure Land Tenure and Sage-Grouse Distributions, ECOSPHERE, Jan. 2016, at 2.

75 Id. at 11. 
on lands only regulated (outside the ESA) by state and local authorities, such a strategy would risk a listing. Thus, state and local governments had a strong incentive not to leave it to federal regulators to go it alone. Rather, the imperative called for states to contribute to the overall goal of enhancing regulatory certainty by adopting regulatory measures to prevent the decline of habitat on private lands within their jurisdictional reach. Only by working together, or at least by making joint contributions to sage grouse conservation, could the goal of a "not warranted" finding be reached.

\section{B. All Threats on All Lands: Knitting Together a Comprehensive Strategy Through Federal-State Cooperation}

The establishment of the 2015 deadline for reconsidering the status of the species opened a four and a half year window for the states and federal land managers to work together to forge a comprehensive plan for conserving sage grouse. The collaboration that followed was uneven and uncertain at times, but resulted in federal and state conservation measures that allowed the FWS to find, in September 2015, that the grouse was not warranted for listing under the ESA. ${ }^{76}$ In some respects the cooperation was less explicit and coordinated than the DRECP, but it was nonetheless extraordinary in its complexity, its scope, and its predicted contribution to the conservation of the greater sage grouse.

Formal cooperation between the federal agencies and the states began in earnest in 2011, when then-Secretary Salazar and Wyoming Governor Matt Mead convened a meeting of federal and state officials. The meeting led to the formation of the Sage Grouse Task Force, chaired by Governor Mead and John Hickenlooper of Colorado. The Sage Grouse Task Force comprised representatives of each of the eleven states with sage grouse habitat, as well as the four federal agencies with primary roles in sage grouse conservation $^{77}$ The role of the Task Force would be "to develop recommendations on how to best advance a coordinated, multi-state, range-wide effort to conserve the sage-grouse, including the identification of conservation objectives to ensure the long-term viability of the species." ${ }^{, 78}$ Upon the recommendation of the Sage Grouse Task Force, and in recognition of the relevant expertise of state wildlife agencies, the FWS director appointed a team of ten state and five FWS scientists with sage grouse expertise to identify the conservation objectives for the sage grouse. ${ }^{79}$ The conservation objectives team

\footnotetext{
76 See generally FWS 2015 Not Warranted Finding, supra note 56.

77 See CONSERVATION OBJeCtives, supra note 62, at 5.

78 Id.

79 Id.
} 
(COT) report became an early benchmark for what threats to the sage grouse would have to be addressed in a comprehensive conservation strategy.

Even before the formation of the Sage Grouse Task Force, the BLM and Forest Service had launched the National Sage Grouse Conservation Strategy, including a sweeping plan to amend ninety-eight land use plans. ${ }^{80}$ Early in this process, the BLM appointed a technical team to identify conservation measures that could be applied on BLM lands to benefit the sage grouse. ${ }^{81}$ This team was predominantly BLM staff, but it also included state wildlife managers from Idaho, Oregon, Nevada, Utah, and Colorado.$^{82}$ The National Technical Team (NTT) issued its report in December 2011, providing, as "a starting point to be used in the BLM's planning processes," a menu of conservation measures that could improve sage grouse conditions in priority habitat. $^{83}$

Though the COT and the NTT were national in scale, the federal land management planning process was decentralized from the start. The BLM prepared separate draft EISs to address sage grouse in fifteen subregions across the range of habitat. ${ }^{84}$ The reasons for this decentralization were largely logistical - the initial draft plan alternatives operated along the usual BLM planning boundaries - but the decentralization had the effect of enhancing the input of states in the early stages of the planning process. As the federal land planning process gained steam, state involvement in the federal land management amendments took the form of specific alternatives proposed by the states, which the BLM analyzed as alternatives in the draft EISs. $^{85}$

State cooperation in understanding the habitat needs of the sage grouse and proposing conservation measures to be applied on federal lands, however, still did not address regulatory mechanisms to be applied on nonfederal lands. So states also developed independent strategies to address threats to

80 Notice of Intent to Prepare Environmental Impact Statements and Supplemental Environmental Impact Statements to Incorporate Greater Sage-Grouse Conservation Measures into Land Use Plans and Land Management Plans, 76 Fed. Reg. 77,008, 77,009-10 (Dec. 9, 2011).

81 See Bureau of Land Mgmt., U.S. DeP'T of the InTERior, A RePOrt on National Greater Sage-Grouse Conservation MEASures 4 (2011).

82 See id. at app. G 74.

83 Id. at $1,5$.

84 Bureau of LAND Mgt., U.S. DeP'T OF THE INTERIOR, RECORD OF DECISION AND APPROVED Resource Management Plan Amendments For the Great Basin Region, Including the Greater SAgE-Grouse Sub-REgIONS OF IDAHO AND SOUTHWESTERN MONTANA NEvADA AND NORTHEASTERN CALIFORNIA OREGON UTAH I-11-I-12 (2015) [hereinafter BLM GREAT BASIN ROD], https://www.blm.gov/or/energy/opportunity/files/gbrod.pdf.

85 See id. at I-12 ("Additionally, the BLM considered State GRSG conservation strategies where they existed, as well as State recommendations for measures to conserve GRSG on BLM-administered lands, where relevant, in its planning."). 
the sage grouse on lands solely within their control ${ }^{86}$ Wyoming, a leader in the state efforts, developed a "core area" strategy that focused on limiting disturbance in the most important areas of sage grouse habitat. ${ }^{87}$ Oregon developed a similar program to protect and enhance sage grouse habitat on State and private lands. ${ }^{88}$ Nevada adopted an innovative, market-based system of mitigation to apply to activities in sage grouse habitat. ${ }^{89}$ These efforts, in addition to the plan amendments on federal land, were considered by the FWS in evaluating whether the conservation outlook had improved enough since 2010 to provide sufficient certainty that threats to the sage grouse would be addressed without ESA listing.

During the process of finalizing both the federal and state plans, the collaboration was unavoidably marked by some friction between states and the federal agencies. Regulation-wary states might have forced the federal land management agencies unilaterally to bear the burden of installing an adequate set of regulatory mechanisms to avoid a listing. But they still had incentive to cooperate. First, demurring might not have successfully avoided a listing, as the feds only managed sixty percent of the habitat, on which even the most stringent conservation measures might well have provided too little certain conservation benefit to the grouse. Second, the states faced potentially unpalatable, stringent regulation on federal lands that might be lessened if sufficient regulation reached activities on State and private land to spread the conservation benefit. This friction was heightened when the BLM and Forest Service decided to meld what had started as fifteen separate planning efforts into a comprehensive strategy with two records of decision. ${ }^{90}$ States feared that their individual circumstances would be lost to a "one size fits all" approach on federal lands. ${ }^{91}$

To be sure, the BLM and Forest Service saw the advantages of a unified and comprehensive strategy adopting common regulatory approaches across the range of plans. ${ }^{92}$ These approaches focused on addressing the threats to sage grouse and their habitat identified in the final COT report using some,

86 FWS 2015 Not Warranted Finding, supra note 56, at 59,874, 59,882-85.

87 See id. at 59,882-83.

88 Id. at $59,884-85$.

89 Id. at 59,932 (describing the Nevada Conservation Credit System).

90 Cally Younger \& Sam Eaton, Lessons Learned from the Greater Sage-Grouse Land Use Planning Effort, 53 IDAHO L. REV. 373, 377 (2017).

91 Id. ("It became increasingly apparent that the federal agencies were going to ignore substantial portions of the state-specific conservation measures in favor of more uniform measures across the species' range.").

92 BLM GREAT BASIN ROD, supra note 84, at I-1 ("The efforts of the BLM, in coordination with the Forest Service on National Forest System lands within the remaining range of the species, constitute a coordinated strategy for conserving the GRSG and the sagebrush-steppe ecosystem on most Federal lands on which the species depends."). 
but not all, of the mechanisms identified by the NTT and the COT. ${ }^{93}$ The heart of the federal regulatory approach involved categorizing the habitat as priority or general and then using science-based regulatory mechanisms to neutralize identified threats in priority habitat and address them in general habitat to sustain sage grouse habitat. ${ }^{94}$ Overall, the federal strategy involved (1) making land use allocations in the management plans, including stipulating the conditions under which activities could occur; (2) limiting surface disturbance in priority areas by implementing a disturbance cap; (3) establishing buffer zones around sage grouse leks to protect breeding behavior; (4) requiring mitigation of surface disturbance to a net conservation gain; (5) embracing an adaptive management strategy with predetermined triggers; and (6) monitoring the status of sage grouse populations and habitat. ${ }^{95}$

Although the final federal plans adopted in each of the planning areas embrace a unified, comprehensive approach, they also reflect substantial tailoring to state regulatory preferences, as well as diverse habitat and economic considerations. In Wyoming, for example, Governor Mead established a state strategy for sage grouse conservation based on the protection of "core areas" of sage grouse habitat. ${ }^{96}$ These core areas differed somewhat from the federal "priority habitat" management areas, and the regulatory approach was based primarily on limiting disturbance to sage grouse core habitat to five percent in accordance with a tool developed by state wildlife managers. ${ }^{97}$ In order to be consistent with Wyoming's "core area" strategy, the federal agencies adopted a more generous disturbance cap than in other areas where no proven strategy had been implemented by the state. ${ }^{98}$ Similarly, Idaho wildlife officials had developed a sage grouse conservation strategy based on three tiers of habitat, rather than two, and the federal plans in Idaho were adjusted to provide greater consistency. ${ }^{99}$ Still, even with these accommodations to effective state strategies and regulatory approaches, several states criticized the

93 See generally id.

94 See, e.g., id. at I-20.

95 Id. In addition, the federal agencies took steps outside the land use planning process to address the threat of loss of sage grouse habitat to fire. These steps included efforts to reduce invasive, fire-friendly grasses and prioritization of sage grouse habitat in wildland firefighting operations. See FWS 2015 Not Warranted Finding, supra note 56, at 59,881-82.

96 See id. at 59,882-83.

97 Id. at 59,879 (five percent in Wyoming and Montana, and three percent in other states).

98 See id. at 59,892-83.

99 See U.S. Forest SERV., U.S. DeP'T OF Agric., Greater SAGE-Grouse RECORD of DeCiSiON FOR IDAHO AND SOUTHWEST MONTANA, NEVADA, AND UTAH 45 (2015), https://www.fs.fed.us/sites/default/files/sage-grouse-great-basin-rod.pdf. 
federal plans as insufficiently deferential to state concerns, ${ }^{100}$ and both Idaho and Utah filed lawsuits challenging the plans. ${ }^{101}$

Despite some bristling at the federal plans, all but one of the states within the range of the sage grouse adopted some kind of conservation plan incorporating new scientific information developed after the "warranted but precluded" finding in 2010. ${ }^{102}$ However, in overall contrast to the federal land management plans, which the FWS specifically found were "regulatory mechanisms" sufficient to increase the regulatory certainty required to mitigate the need for listing under the ESA, ${ }^{103}$ many of the state plans were too weak or too late for the FWS to deem them regulatory. ${ }^{104}$ Nonetheless, Wyoming's, Montana's, and Oregon's state-level conservation plans gained credit for their contribution to the overall level of sage grouse conservation certain to be implemented and effective. ${ }^{105}$ Even if the other state plans came too late to contribute to the 2015 not warranted finding, ${ }^{106}$ they represent significant cooperation by the states with the overall federal effort, and they might contribute to conservation in ways that would be recognized in future status reviews by FWS.

The FWS's 2015 finding that the sage grouse was not warranted for listing under the ESA, in sum, was the plain result of massive cooperation between federal agencies and the states. Put another way, without the extraordinary cooperation of various agencies and officials across jurisdictional lines, the FWS would likely have been unable to reach the scientific conclusion that the sage grouse was not warranted for listing. And the fruit of the collaboration is not just the conservation of the sage grouse on terms not dictated by sections 7 and 9 of the ESA; it is quite possibly the survival of the ESA in its current form. A listing of the sage grouse would potentially have set off a wave of antipathy toward the ESA, with widespread regional support, that could lead to wholesale revision of the ESA. Rather, the regulatory

100 See, e.g., Younger \& Eaton, supra note 90.

101 See Rocky Barker, Judge Tosses Otter's Sage Grouse Lawsuit Against Obama Administration, IDAHO STATESMAN (Jan. 5, 2017, 4:57 PM), http://www.idahostatesman.com/news/local/news-columnsblogs/letters-from-the-west/article124837944.html.

102 FWS 2015 Not Warranted Finding, supra note 56, at 59,931.

103 Id. at 59,874-75.

104 Id. at 59,884 ("We appreciate the work that each state has completed, but we could not include all planning efforts ... in our analysis because they did not meet a level of certainty for implementation and effectiveness.”).

$105 I d$. at $59,884-85$

106 A helpful factor in establishing the effectiveness of conservation measures on private lands notwithstanding the shortcomings of the state plans was the Sage Grouse Initiative (SGI), a program of the Department of Agriculture's Natural Resources Conservation Service. Under the auspices of the SGI, $\$ 425$ million was invested in partnerships with more than 1,100 ranches to design and implement sage grouse conservation measures on private lands, including grazing management systems, conservation easements, and restoration projects. See id. at 59,886. 
mechanisms and other conservation efforts put into place across the range of the sage grouse stand as a hallmark of the collaborative conservation perhaps made possible only with the threat of a listing.

\section{Conclusion: The Future of Collaborative CONSERVATION MANAGEMENT IN THE TRUMP ERA}

The stories of the epic collaborations of the DRECP and sage grouse conservation, coming to fruition as they did toward the end of President Obama's administration, beg the question: Will they last, or, like so many other Obama policies, will they be simply revoked or rolled back? A year into the Trump administration, the forecast seems to call mostly cloudy. Nonetheless, the imperatives of federal-state cooperation in both contexts may provide just enough stability to retain them in substantial form. Even if President Trump decides to roll back the conservation efforts, the imperatives will likely lie in wait for a future president to act upon.

The Trump administration has announced its intent to reconsider the DRECP in light of policy direction to "remove impediments" to domestic energy production. And the policy direction of his administration is decidedly away from promoting renewable energy development: Trump has said the U.S. will pull out of the Paris Accord, whose targets provided strong incentives for renewables development. ${ }^{107} \mathrm{He}$ has vowed to revive the coal industry, ${ }^{108}$ and his administration has launched several policy initiatives that erode U.S. commitment to renewable energy development. For example, the Department of Energy proposed a rule that would disadvantage renewable energy by ensuring price subsidies for energy produced by fossil fuels and nuclear plants on the grounds that such energy supports grid reliability. ${ }^{109}$ Moreover, Secretary of the Interior Zinke has publicly questioned whether large scale renewable energy development is a wise use of public land, and the BLM is reportedly considering whether to revoke the withdrawals in the designated renewable energy development zones, which would subject those

107 Statement by President Trump on the Paris Climate Accord, WHITE House (June 1, 2017), https://www.whitehouse.gov/briefings-statements/statement-president-trump-paris-climate-accord/.

108 Michael Grunwald, Trump's Love Affair with Coal, Politico MaG. (Oct. 15, 2017), https:/www.politico.com/magazine/story/2017/10/15/trumps-love-affair-with-coal-215710.

109 See Grid Resiliency Pricing Rule, 82 Fed. Reg. 46,940, 46,945 (proposed Oct. 10, 2017) (to be codified at 18 C.F.R. pt. 35); Letter from Rick Perry, Sec'y of Energy, to Neil Chatterjee, Chairman, Cheryl A. LaFleur, Comm'r, \& Robert F. Powelson, Comm'r, Fed. Energy Regulatory Comm'n (Sept. 28, 2017), https:/energy.gov/sites/prod/files/2017/09/f37/Secretary\%20Rick\%20Perry\%27s\%20Letter $\% 20$ to $\% 20$ the $\% 20$ Federal $\% 20$ Energy $\% 20$ Regulatory $\% 20$ Commission.pdf. 
areas to potential conflicts from mining claims. ${ }^{110}$ These developments portend the potential demise of the federal portion of the DRECP.

The Trump administration's commitment to the comprehensive sage grouse conservation strategy is even less secure. In response to recommendations of a task force that reviewed the federal land management plans for sage grouse and their impact on energy production, ${ }^{111}$ the Interior Department announced a new process to amend the sage grouse plans. ${ }^{112}$ It unveiled specific proposals it is considering in May 2018. ${ }^{113}$ Although some states would likely welcome changes to the sage grouse conservation plans - most notably, Idaho and Utah, which challenged the 2015 plans in court-Governors Hickenlooper of Colorado and Mead of Wyoming, who co-chair the Sage Grouse Task Force, indicate that they oppose wholesale changes, arguing instead for minor adjustments developed through continued coordination between state and federal wildlife experts. ${ }^{114}$ Governor Sandoval of Nevada has also expressed concerns with amending the plans, particularly moving toward a population-based rather than habitat-based approach to conservation. ${ }^{115}$

However wavering President Trump's commitment to renewable energy and to conservation of sage grouse habitats, there is a strong imperative for continued federal-state cooperation in both the California desert and across the range of the sage grouse. Weakening the federal policy emphasis on renewable energy development will not and cannot change the fact that California's drive toward ever higher proportions of renewable energy on its grid will continue to drive demand for renewable electric generation. Nor will it change that California law will demand a high standard of mitigation for impacts of energy development on species of concern and their habitat - mitigation that will often best be provided from conservation actions on federal public land. Similarly, a federal drive away from habitat-based conservation

110 Scott Streater, BLM Proposal Would Revive Mining in Renewable Energy Zone, E\&E NEWS (Oct. 5, 2017), https://www.eenews.net/stories/1060062795.

111 See Lisa Friedman, Interior Department to Overhaul Obama's Sage Grouse Protection Plan, N.Y. TIMES (Sept. 28, 2017), https://www.nytimes.com/2017/09/28/climate/trump-sage-grouse.html.

112 Notice of Intent to Amend Land Use Plans Regarding Greater Sage-Grouse Conservation and Prepare Associated Environmental Impact Statements or Environmental Assessments, 82 Fed. Reg. 47,248, 47,248 (Oct. 11, 2017).

113 E.g., Notice of Availability of the Nevada and Northeastern California Draft Resource Management Plan Amendment and Draft Environmental Impact Statement for Greater Sage-Grouse Conservation, 83 Fed. Reg. 19,800 (May 4, 2018).

114 See Letter from John Hickenlooper, Colo. Governor, \& Matthew H. Mead, Wyo. Governor, to Ryan Zinke, Sec'y of the Interior (May 26, 2017), https://www.epw.senate.gov/public/_cache/files/0f6caa4b-e2ec-418f-97e0-55d2ab047c11/2017-5-26-mead-hickenlooper-sage-grousepopulation-model-002-.pdf.

115 Riley Snyder, Sandoval Joins Other Governors in Questioning Aspects of Federal Sage Grouse Conservation Plans, NEV. INDEP. (Aug. 19, 2017, 2:10 AM), https://thenevadaindependent.com/article/sandoval-joins-other-governors-in-questioning-aspects-of-federal-sage-grouse-conservation-plans. 
strategies for the sage grouse will not change the fact that state wildlife scientists do not believe focusing on populations alone is sufficient to stop the decline of the species. Nor will slackening sage grouse protections on federal land do much to encourage necessary protections under state law on the nearly forty percent of habitat that is beyond the reach of federal law unless the bird is listed under the ESA. And, most important, the specter of a listing under the ESA will continue to exert powerful reasons for continued federalstate cooperation in effective sage grouse conservation. By any reasonable reckoning, the prospect of stringent but self-determined regulation to protect sage grouse is more palatable than the extensive regulatory regime that would govern if the bird were listed.

So, though policy may change in response to political shifts, the biological and legal imperatives for federal-state collaboration in conservation planning are perhaps a bit like the forces of nature. They will inexorably push the separate sovereigns to come together to try to solve the puzzles posed by the patchwork of land ownership and jurisdiction. Only real legal change, in the form of gutting the ESA or exempting the sage grouse from its reach, ${ }^{116}$ will alter those imperatives.

116 Sadly, this prospect is not unthinkable. In the years leading up to the 2015 sage grouse plans and listing determination, numerous appropriations riders addressing the sage grouse were introduced. Most, such as one that would have mandated the BLM to follow state-adopted plans for sage grouse conservation, were defeated. See, e.g., Amanda Reilly, et al., Jewell, Enviros Slam 'Dreadful' Policy Riders in Interior-EPA Bill, E\&E NEWS (June 10, 2015), https://www.eenews.net/stories/1060019954. Others met with some success, such as a rider passed in 2014 that prohibited the FWS from spending money on writing any rule that would list the sage grouse under the ESA. See, e.g., Phil Taylor, Sage Grouse RiderWhat it All Means, E\&E NEWs (Dec. 12, 2014), https://www.eenews.net/stories/1060010499. The likelihood that either of these ideas would resurface to change the legal landscape may well depend on the makeup of the Congress after the 2018 election cycle. 